monetary institutions that mismanage the nations' wealth.

\section{Bassem Saab and Jumana Antoun}

\section{Acknowledgement}

We like to thank Doctor Rasha Hamra from the Ministry of Health for providing us with valuable data.

\section{REFERENCES}

1. Cameron A, Ewen M, Ross-Degnan D, et al. Medicine prices, availability, and affordability in 36 developing and middle-income countries: a secondary analysis. Lancet 2009; 373(9659): 240-249.

2. Zinner DE, Bjankovic D, Clarridge B, et al. Participation of academic scientists in relationships with industry. Health Aff (Millwood) 2009; 28: 1814-1825.

3. Forgacs I, Loganayagam, A. Overprescribing proton pump inhibitors. BMJ 2008; 336(7634): 2-3.

4. Saab B. Health for All? Dream On! Br J Gen Pract 2009; 59(558): 55.

5. Ariste R, Fortin G. Could MRI and CT Scanners be operated more intensively in Canada? Healthc Policy 2007; 3(1):e113-e120.

6. Segelov E. The emperor's new clothes - can chemotherapy survive? Aust Prescr 2006; 29: 2-3.

7. Park SJ, Park DW. Percutaneous coronary intervention with stent implantation versus coronary artery bypass surgery for treatment of left main coronary artery disease: is it time to change guidelines? Circ Cardiovasc Interv 2009: 2(1): 59-68.

8. Morrison D. PCI versus CABG versus medical therapy in 2006. Minerva Cardioangiol 2006: 54(5): 643-672.

DOI: 10.3399/bjgp10X483715

consistently prioritised over the demands of the well.

\section{Iona Heath}

\section{f... it is an \\ issue of \\ intergenerat- ional justice.}

\title{
How to cut NHS spending and improve the health of the nation
}

The immediate response of all the major political parties to the current crisis of public expenditure is to reassure the public that the NHS will be protected from the scale of spending cuts considered essential in other areas of the public sector. This is unfortunate because it is readily apparent, not only that vast resources are wasted in the NHS, but that much health service expenditure is more likely to make people ill than improve their health.

In The Rise and Fall of Modern Medicine, GP and writer James LeFanu exposed the malign influence of 'risk factor epidemiology' on public health and proposed a radical solution:

'The simple expedient of closing down most university departments of epidemiology could both extinguish this endlessly fertile source of anxietymongering while simultaneously releasing funds for serious research."

In the decade since LeFanu's book was published, increasingly authoritarian and intrusive health promotion and disease prevention campaigns based on dubious epidemiology have become a major focus of government expenditure and medical intervention (not least in primary care). The current crisis provides the ideal opportunity to implement LeFanu's proposal - and to extend its scope to the wider world of public health.

The great swine flu pandemic provides an apt symbol of resources wasted in the cause of scaremongering based on dodgy epidemiology. This follows the panics over AIDS, mad cow disease, SARS and bird flu in generating bloated bureaucracies consuming millions while provoking public anxieties out of all proportion to real risk. According to Labour MP Paul Flynn, more than $£ 1$ billion has been spent on pandemic preparations since 2005, including the purchase of 1.1 million courses of largely unused (and largely useless) antivirals, which he has suggested 'would be great for gritting the icy roads'.

In the same week that Flynn warned parliament of the dangers of crying wolf over pandemics, another parliamentary committee condemned the Chlamydia testing programme overseen by the Health Promotion Agency and implemented by primary care trusts as 'inefficient and wasteful'. ${ }^{3}$ This campaign could also stand as a symbo of numerous health promotion initiatives over the past decade.

It seems that almost very week a new report is published proclaiming that some familiar target of public health propaganda has reached epidemic (if not pandemic) proportions: alcohol consumption, obesity, drug abuse, domestic violence, teenage pregnancy. The familiar response proclaimed by politicians and medical entrepreneurs, and dutifully endorsed by the media, is that we need to devote even more resources to the sort of health promotion campaigns that have failed to prevent these problems from reaching such threatening proportions over the past decade. The sensible response, encouraged by the new climate of fiscal austerity (not to mention the unreliability of the claims for the scale of these problems), would be to abandon all these programmes and to stop throwing good money after bad.

Although I am reluctant to suggest any further structural reforms in the NHS, the abolition of PCTs looks a promising way of saving money and improving primary care at a stroke. Now that the PCTs seem to exist largely to transmit public health propaganda from the government to local services and to 'roll out' the latest fashionable initiative from the Department of Health, I don't think we would miss them. And while taking the axe to epidemiology departments, perhaps the auditors could take a look at academic departments of general practice. What are they good for?

\section{REFERENCES}

1. LeFanu J. The rise and fall of modern medicine. London: Little Brown, 1999.

2. Kmietowicz Z. Use leftover Tamiflu to grit icy roads, MP suggests. BMJ 2010; 340: c501.

3. Mooney H. England's chlamydia screening programme is patchy and inept. BMJ 2010:340: c539.

DOI: 10.3399/bjgp10X483733 